Научная статья

УДК 579.2(517.3)

DOI: $10.18101 / 2542-0623-2021-4-82-91$

\title{
АКТИНОБАКТЕРИИ ТЕРМАЛЬНОГО ИСТОЧНИКА ЕРО (МОНГОЛИЯ)
}

П. А. Ткачёв, А. А. Раднагуруева, Е. В. Лаврентьева,

Т. Г. Банзаракцаева, Д. Д. Бархутова, В. Б. Дамбаев, С. П. Бурюхаев, Г. Алтанцэцэг, Г. Орхонтуяа, Р. Юндонперенлей

(C) Ткачёв Павел Алексеевич

магистрант,

Бурятский государственный университет имени Доржи Банзарова

Россия, 670000, г. Улан-Удэ, ул. Смолина, 24а

pashenka.tkachev.2016@list.ru

(C) Раднагуруева Арюна Арсалановна

кандидат биологических наук,

Институт общей и экспериментальной биологии СО РАН

Россия, 670047, г. Улан-Удэ, ул. Сахьяновой, 6

aryuna_rg@mail.ru

\section{(C) Лаврентьева Елена Владимировна}

кандидат биологических наук,

Институт общей и экспериментальной биологии СО РАН

Россия, 670047, г. Улан-Удэ, ул. Сахьяновой, 6

Бурятский государственный университет имени Доржи Банзарова

Россия, 670000, г. Улан-Удэ, ул. Смолина, 24а

lena 1@mail.ru

\section{(C) Банзаракцаева Туяна Геннадьевна}

кандидат биологических наук,

Институт общей и экспериментальной биологии СО РАН

Россия, 670047, г. Улан-Удэ, ул. Сахьяновой, 6

tuyana_banz@mail.ru

\section{(c) Бархутова Дарима Дондоковна}

кандидат биологических наук,

заведующий лабораторией микробиологии,

Институт общей и экспериментальной биологии СО РАН, Россия, 670047, Улан-Удэ, ул. Сахьяновой, 6;

darima_bar@mail.ru

\section{(C) Дамбаев Вячеслав Борисович}

кандидат биологических наук,

Институт общей и экспериментальной биологии СО РАН

Россия, 670047, г. Улан-Удэ, ул. Сахьяновой, 6

slavadmb@mail.ru 
Ткачев П. А. и др. Актинобактерии термального источника Еро (Монголия)

\section{(C) Бурюхаев Савелий Петрович}

кандидат биологических наук,

Институт общей и экспериментальной биологии СО РАН

Россия, 670047, г. Улан-Удэ, ул. Сахьяновой, 6

bursav@mail.ru

\section{(C) Гандбол Алтанцэцэг}

аспирант,

Медицинский университет «Новая медицина»,

Монголия, 18130, г. Улан-Батор, р-н Сонгинохайрхан-20, ул. Сонсголон Товчооны, 5/2

altantsetseg@ncm.edu.mn

\section{(C) Гантулга Орхонтуяа}

аспирант,

Медицинский университет «Новая медицина»,

Монголия, 18130, г. Улан-Батор, р-н Сонгинохайрхан-20, ул. Сонсголон Товчооны, 5/2

orkhontuya@ncm.edu.mn

\section{(c) Раднасед Юндонперенлей}

аспирант,

Медицинский университет «Новая медицина»,

Монголия, 18130, г. Улан-Батор, р-н Сонгинохайрхан-20, ул. Сонсголон Товчооны, 5/2

altantsetseg@ncm.edu.mn

Аннотация. Статья посвящена изучению актинобактерий в термальном источнике Монголии - Еро. В горячем источнике Еро был проведен таксономический анализ микробного сообщества воды, микробного мата и донных осадков с помощью метода высокопроизводительного секвенирования по гену $16 \mathrm{~S}$ рРНК. Показано, что наибольшая доля актинобактерий обнаружена в воде горячего источника (до 42\%), наименьшее разнообразие актинобактерий обнаружено в образцах микробных матов (до 0,3\%). Из донных осадков станции Еро-19-3 выделена культура актинобактерии Nocardia farcinica. Выделенный штамм актинобактерии является умеренным термофилом с оптимумом роста $45^{\circ} \mathrm{C}$

Ключевые слова: высокопроизводительное секвенирование по гену $16 \mathrm{~S}$ рРНК, горячие источники, актинобактерии, термофилы.

Благодарности. Работа выполнена в рамках темы госзадания № госрегистрации 121030100229-1.

\section{Для цитирования}

Актинобактерии термального источника Еро (Монголия) / П. А. Ткачев, А. А. Раднагуруева, Е. В. Лаврентьева, Т. Г. Банзаракцаева, Д. Д. Бархутова, В. Б. Дамбаев, С. П. Бурюхаев, Г. Алтанцэцэг, Г. Орхонтуяа, Р. Юндонперенлей // Природа Внутренней Азии. Nature of Inner Asia. 2021. № 4(19). C. 82-91. DOI: 10.18101/2542-0623-2021-4-82-91

\section{Введение}

На территории Монголии широко распространены термальные источники, которые являются естественными местами обитания микроорганизмов. Актинобактерии, обитающие в горячих источниках, разработали уникальные 
биохимические метаболические и физиологические возможности, которые обеспечивают как выживание, так и потенциал для биосинтеза различных антибиотиков и новых метаболитов [Yang N. \& Song].

Актинобактерии - это грамположительные бактерии с высоким содержанием гуанина+цитозина и могут быть представлены как нитчатыми, так и формами, не образующими нити, некоторые могут продуцировать споры на различных этапах онтогенеза. По современной классификации филум Actinobacteria включает 6 классов, 6 отрядов, 14 подотрядов и 56 семейств [J.Wink, F. Mohammadipanah 2017]. Количество интродуцированных родов этого таксона и их физиологическое разнообразие предполагает, что таксономическая идентификация этой группы будет динамичным процессом в будущем. Актинобатерии могут быть представлены как сапрофитами, так и патогенными микроорганизмами. Благодаря большому разнообразию ферментных комплексов и антибактериальному потенциалу актинобактерии используют в медицине, промышленности и энергетике и для решения проблем окружающей среды [J.Wink, F. Mohammadipanah 2017]. Экологическая роль актинобактерий в природных системах заключается в разложении сложных устойчивых субстратов, в то же время из-за медленного роста они неспособны конкурировать с немицелиальными бактериями за легкодоступные вещества. Представители рода Nocardia способны осуществлять процессы хемосинтеза, окисляя водород, метан и метанол. Среди актиномицетов широко распространена гетеротрофная фиксация $\mathrm{CO}_{2}$ [Ю.Н. Горелов и др, 2012].

Микробные сообщества в горячих источниках широко изучаются с использованием как культурально-зависимым, так и культурально-независимым подходом. Так использование методов высокопроизводительного секвенирования $16 \mathrm{~S}$ рРНК оказалось многообещающим инструментом для исследования популяционного разнообразия и экологической значимости микробных сообществ, обитающих в различных горячих источниках. Использование культурально-зависимого подхода необходим для изоляции и идентификации бактерий с высоким биотехнологическим потенциалом. Исследование рассматриваемого горячего источника Еро с использованием культурально-независимого и культурально-зависимого подходов расширят данные по таксономическому разнообразию актинобактерий.

\section{Материал и методика}

Объектом исследования является горячий источник Байкальской рифтовой зоны - Еро (Монголия) с диапазоном температур от $36,3{ }^{\circ} \mathrm{C}$ до $42,9{ }^{\circ} \mathrm{C}$. Источник расположен на северо-западном склоне Хэнтэйского хребта, в 150 км к северу северо-востоку от г. Улан-Батор, в труднодоступной горно-таёжной местности, на левом берегу р. Ара-Ичильхэ, GPS: 4901'122" с. ш., 107³2'727" в. д. [Оргильянов, 2021].

Накопительную культуру актинобактерий культивировали на среде состава (г/л): $\mathrm{NH}_{4} \mathrm{Cl}-0,3 ; \mathrm{KH}_{2} \mathrm{PO}_{4}-0,3 ; \mathrm{MgCl}_{2}-0,3 ; \mathrm{CaCl}_{2}-0,3$; дрожжевой экстракт - 0,5. В качестве источника азота использовали триптон в конечной концентрации $1,5 \%$. Оптимальные значения $\mathrm{pH}^{25 \mathrm{C}}$ роста бактерий устанавливали карбонат-бикарбонатным буфером до $\mathrm{pH}$ 8,5-9,0. Посевы осуществляли методом предельных разведений (1:10), аэробно, в термостате Binder (Германия). Культуры инкубировались при $45^{\circ} \mathrm{C}$ в течение трех суток. 
Ткачев П. А. и др. Актинобактерии термального источника Еро (Монголия)

Таблица 1

Физико-химическая характеристика источника Еро (апрель, 2019)

\begin{tabular}{|c|c|c|c|c|c|c|}
\hline Станция & $\mathrm{T},{ }^{0} \mathrm{C}$ & $\mathrm{pH}$ & $\mathrm{M}, \mathrm{мг} /$ Л & $\mathrm{Eh}, \mathrm{mB}$ & $\mathrm{CO}_{3}^{2-}, \mathrm{Mг} / \Omega$ & $\mathrm{HCO}_{3}^{-}, \mathrm{Mг} / \Omega$ \\
\hline Еро-1 & 42.9 & 9.27 & 232 & -241 & 30 & 30.5 \\
\hline Еро-2 & 41.2 & 9.34 & 232 & -237 & 36 & 24.4 \\
\hline Еро-3 & 40.9 & 9.92 & 233 & -119 & 30 & 36.6 \\
\hline Еро-4 & 36.3 & 9.48 & 236 & $-99--101$ & 36 & 18.3 \\
\hline
\end{tabular}

Для выделения чистой культуры из отдельной колонии накопительной культуры высевали поверхностным способом в стерильные чашки Петри с агаризованной средой. Изолированные колонии пересевали вновь. Чистоту выделенных культур проверяли микроскопированием по однородности клеток. Микроскопирование культур проводили с помощью микроскопа Axiostar plus (Carl Zeiss, Германия) при увеличении 1000 раз в фазовом контрасте на окрашенных препаратах по Граму.

Исследование таксономического состава микробного сообщества проводились с помощью высокопроизводительного секвенирования фрагментов генов $16 \mathrm{~S}$ pРНК. Проведена качественная и количественная характеристика состава бактериальных сообществ донных осадков и микробных матов в горячем источнике Еро. Секвенирование продуктов амплификации выполняли в ЦКП «Персистенция микроорганизмов» (г. Оренбург).

ДНК выделяли с помощью набора PowerSoil DNA Isolation Kit (Mo-Bio). Регион V3-V4 гена $16 \mathrm{~S}$ рРНК был амплифицирован с помощью праймеров 343F (5'-CTCCTACGGRRSGCAGCA-3') and 806R (5'-GGACTACNVGGGTWTCTAAT-3'), содержащих адаптерные последовательности (Illumina), линкер и баркод. Биоинформатическая обработка включала перекрывание парных ридов, фильтрацию по качеству и длине, учет одинаковых последовательностей, отбрасывание синглетонов, удаление химер и кластеризацию, и получение OTU. Таксономическая принадлежность последовательностей OTU определялось с помощью RDP classifier 2.11 [Wang et al., 2007].

\section{Результаты и обсуждение}

Для изучения состава микробного сообщества источника Еро было проведено высокопроизводительное секвенирование по гену $16 \mathrm{~S}$ рРНК. По результатам секвенирования показано, что микробное сообщество донных осадков источника Еро характеризовалось значительным видовым разнообразием бактерий, в составе которых выявлено до 349 филотипов (OTU), принадлежащих 32 филумам. Определено от 37132 до 55196 последовательностей, бактерии составляют до 98,45\% микроорганизмов в донных осадках станции Еро-19-3 и 98,73 \% микроорганизмов в осадках станции Еро-19-2. В источнике Еро микробные сообщества донных осадков четырех станций сходны по наличию представителей основных филумов бактерий. От 50,5\% до 93,68\% всех последовательностей микробного сообщества донных осадков четырех станций составляют 5 филумов Proteobacteria, Cyanobacteria/Chloroplast, Chloroflexi, Nitrospitae и Unclassified_Bacteria, доля последних составляет от 8,45 до $28,9 \%$ от всех последовательностей. В донных осадках обнаружены последовательности до 1,44\%, относящиеся к Archae. 
Наибольшее количество нуклеотидных последовательностей в сообществе микробных матов принадлежало представителям следующих таксонов: Proteobacteria, Cyanobacteria/Chloroplast, Chloroflexi, и Unclassified_Bacteria. Чуть менее половины последовательностей $(47,98 \%)$ в станции Еро-19-2 относится к Unclassified Bacteria.

Микробное сообщество воды источника Еро отличалось доминированием двух филумов Proteobacteria и Actinobacteria. Эти филумы составляют более 92\% состава микробного сообщества воды станций Еро-19-1, Еро-19-2 и Еро19-4. Станция Еро-19-3 отличается наименьшим разнообразием актинобактерий. Доминируют Proteobacteria (61,72\%) остальные последовательности составляют филумы Bacteroidetes, Cyanobacteria/Chloroplast, Firmicutes, Ignavibacteriae, Unclassified_Bacteria, Verrucomicrobia и Nitrospirae.

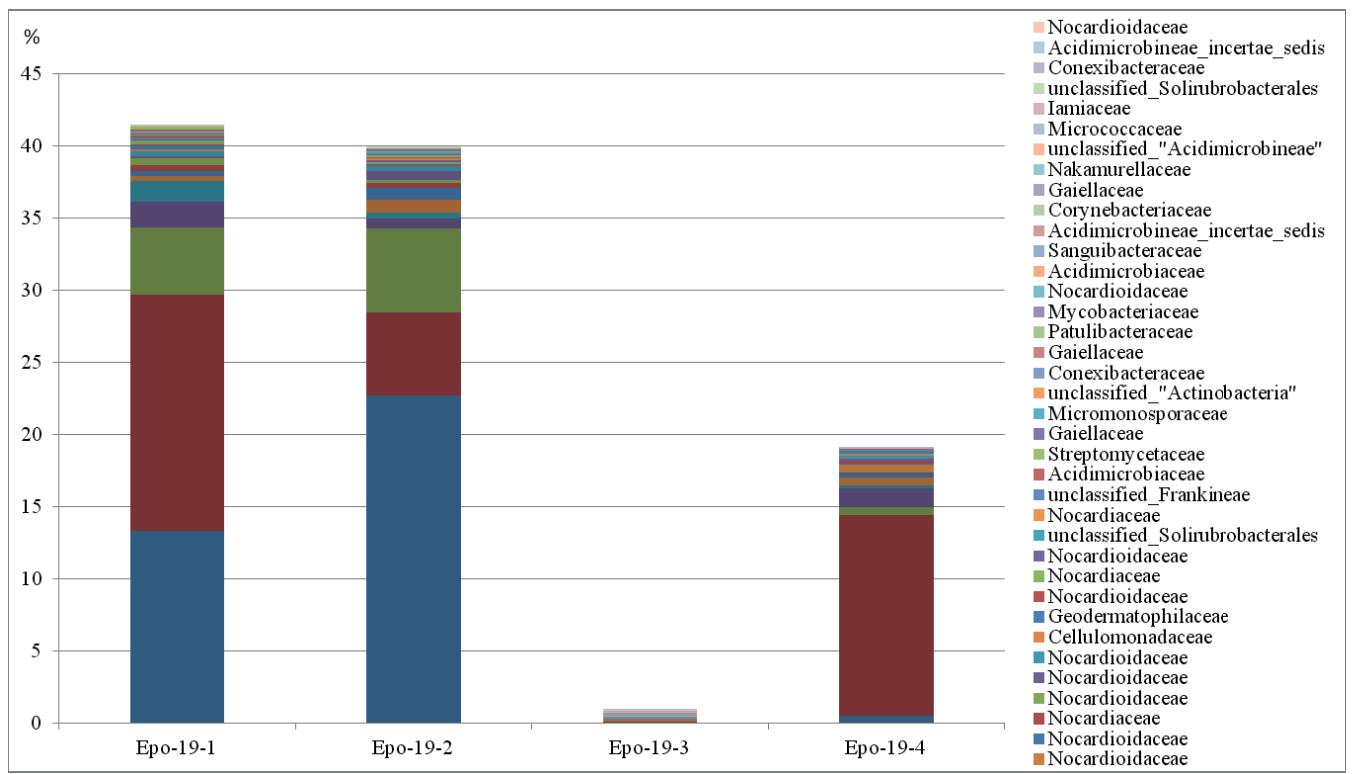

Puc. 1. Разнообразие филума Actinobacteria в воде термального источника Еро на уровне семейства

В микробных матах содержание актинобактерий, в зависимости от выходов, составляет от 1,1-1,3\%. Разнообразие класса актинобактерий, составляют порядки Acidimicribiales, Gaiellales, Coriobacteriales и unclassified_Actinibacteria. Acidimicrobiales включает в себя семейства Lamiacea, Acidimicrobinaeae_incertae_sedis и unclasiffied_Acidimicrobinae. Gaiellales имеет только семейство Gaiellaceae, представленные одним родом - Gaiella. Порядок Coriobacteriales представлен семейством Coriobacteriaceae, с единственным родом - unclassified_Coriobacteriaceae. Семейство Lamiacea состоит только из рода - Aquihabitans.

Таксономический анализ актинобактерий в донных осадках показал, что видовой состав на уровне порядка существенно отличался от таксономического разнообразия воды и микробных матов (рис. 3). 
Ткачев П. А. и др. Актинобактерии термального источника Еро (Монголия)

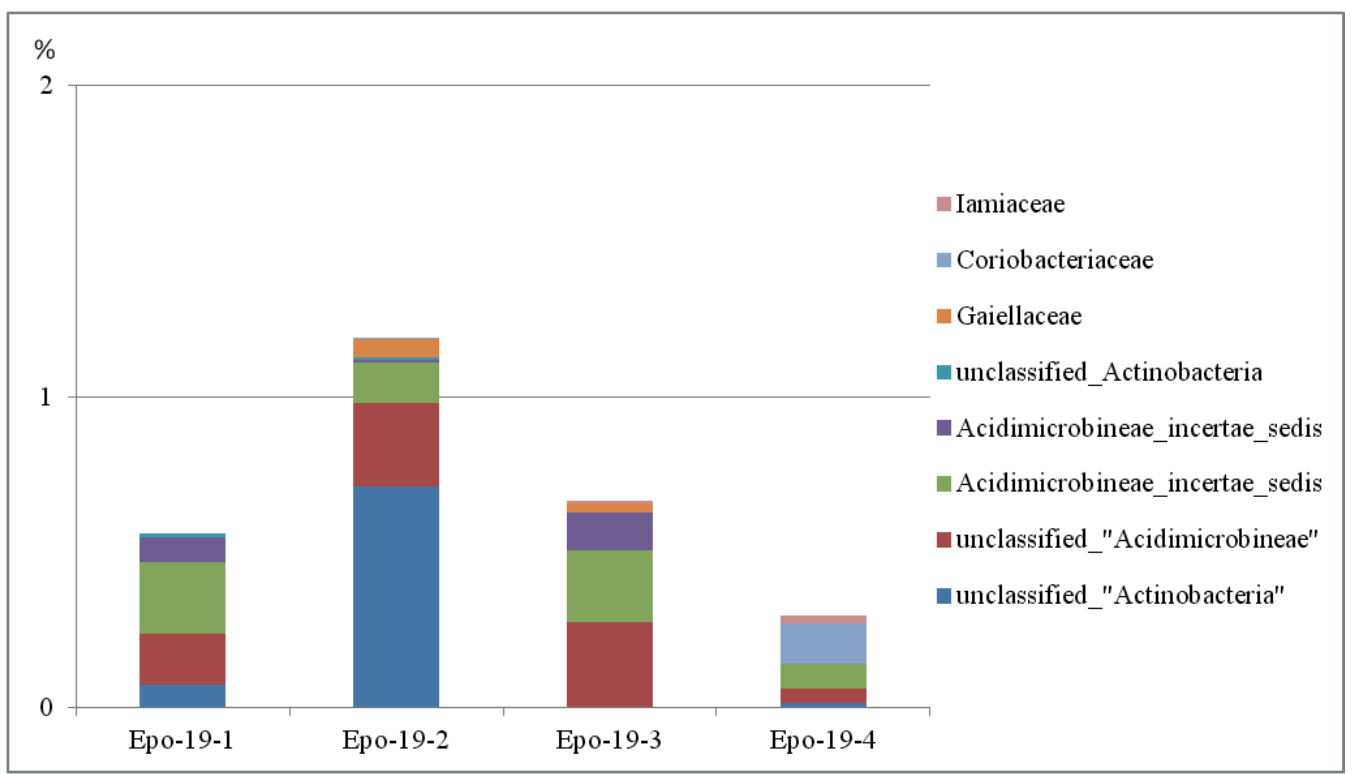

Puc. 2. Разнообразие филума Actinobacteria в микробных матах термального источника Еро на уровне семейства

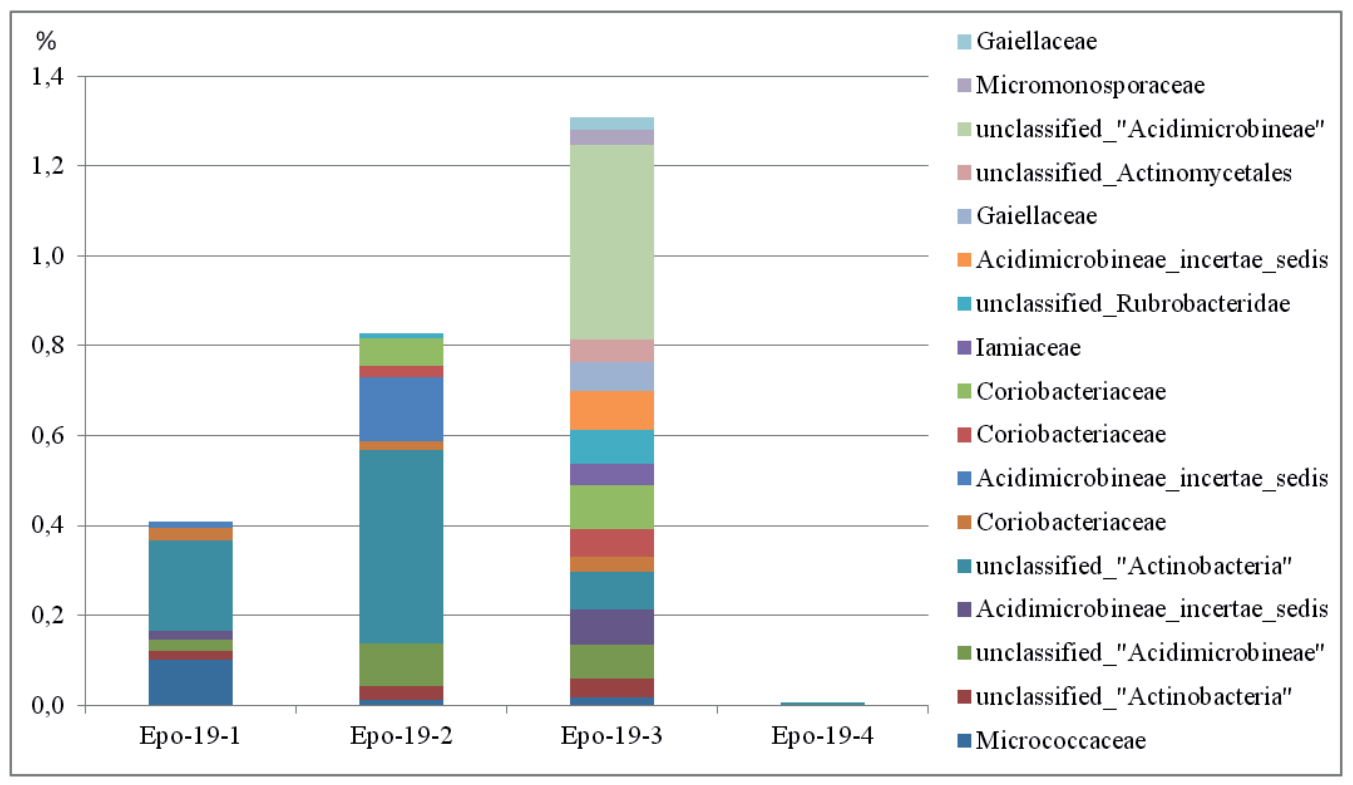

Puc. 3. Разнообразие филума Actinobacteria в донных осадках термального источника Еро на уровне семейства

В данных осадках филум актинобактерий представлен следующими порядками: Acidimicrobiales, Actinomycetales, Gaiellales и Coriobacteriales. Из всех последовательностей представленных Actinobacteria в донных осадках на долю неклассифицируемых приходится от 67,5 до 81,8\% (от всех последовательностей, 
отнесенных к филуму Actinobacteria). Высокий процент неклассифицируемых актинобактерий в донных осадках горячего источника Еро представляет собой новый и неиспользованный ресурс видового разнообразия и требует дальнейшего изучения.

Из термального источника Еро (Монголия) была выделена одна монокультура бактерии. Штамм был выделен из накопительной культуры донных осадков станции Еро-19-3. Культура представлена тонкими, но длинными и извитыми бактериями, которые могут сцепляться друг с другом и образуют длинную цепь, размеры которой достигали около 0,8 мкм, также имеет клеточные образования жгутики. Структура клеточной стенки изолята имеет грамположительный тип. На агаризованной среде штамм образует округлые темно-оранжевые колонии диаметром 2-3 мм, с ровными краями и гладкой блестящей поверхностью. Данная бактерия довольно плохо культивируется, требует специальной техники пересева. В результате определения таксономической принадлежности бактерии на основании морфологических признаков и микроскопических методов культура отнесена к представителям рода Nocardia, класса Actinobacteria (рис. 4). При определении и описании культуры учитывали следующие характеристики: форма и окраска, наличие дополнительных образований, количество клеток в колониях, особенности ветвления и другие характеристики. Выделенный штамм бактерии является умеренным термофилом с оптимумом роста $45^{\circ} \mathrm{C}$.

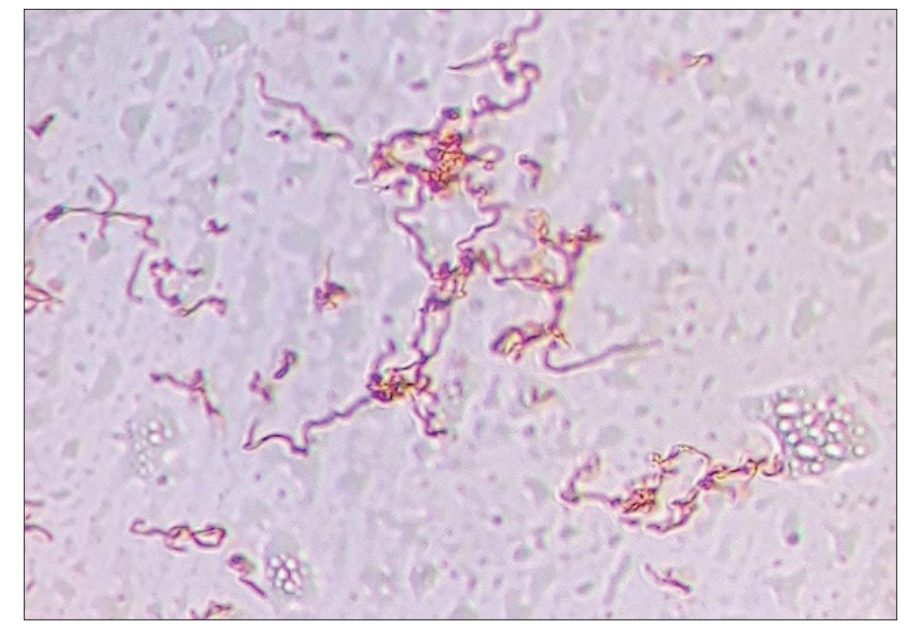

Puc. 4. Актинобактерия, род Nocardia, предположительно Nocardia farcinica

Всего в мире насчитывается более 80 видов нокардий и около 33 видов, являются условно-патогенными организмами [Wink, 2012].

Таким образом, изучено таксономическое разнообразие актинобактерий в составе микробного сообщества в горячем источнике Еро (Монголия). Показано, что доля актинобактерии в сообществе варьировала, в зависимости от биотопа: вода, донные осадки и микробные маты. Следует отметить, что в микробном сообществе горячего источника Еро обнаружена высокая доля неклассифицируемых бактерий. Впервые в горячем источнике Монголии была выделена чистая культура филума Actinobacteria. 


\section{Литература}

1. Оргильянов А. И. Минеральные воды Хэнтэй-Даурского свода : диссертация на соискание ученой степени кандидата геологических наук. Иркутск 2021. 152 с. Текст : непосредственный.

2. Энциклопедия Самарской области / Министерство образования и науки Самарской облости; редакционный совет: Ю. Н. Горелов [и др.]. Самара : СамЛюксПринт, 2011. Т. 4: Н-P. 316 с. Текст : непосредственный.

3. Wang Z., Gerstein M., Snyder M. RNA - Seq: a revolutionary tool for transcriptomics // Nature Reviews Genetics. 2009. V. 10. No. 1. P. 57-63.

4. Arjan P., Heijmans K., Harhangi Harry R., Tedesco Dario, Jetten Mike S. M., Op Den Camp Huub J. M. Methanotrophy below pH 1 by a new Verrucomicrobia species // Nature. 2007. V. 450. P. 874-878.

5. Wink J., Mohammadipanah F. and Hamedi J. Biology and biotechnology of Actinobacteria 2017. 1 c.

6. Wink J. Nocardiosis: updates and clinical overview. Mayo Clin. Proc. 2012. No. 87(4). P. 403-407.

7. Yang N. \& Song F. Bioprospecting of Novel and Bioactive Compounds from Marine Actinomycetes Isolated from South China Sea Sediments // Curr. Microbiol. 2018. No. 75. P. 142-149. URL : https://doi.org/10.1007/s00284-017-1358-Z

Статья поступила в редакциию 04.10.2021; одобрена после рецензирования 17.11.2021; принята к публикации 20.12.2021.

\section{ACTINOBACTERIA OF THERMAL SPRING ERO (MONGOLIA)}

P. A. Tkachyov, A. A. Radnagurueva, E. V. Lavrentyeva,

T. G. Banzaraktsaeva, D. D. Barkhutova, V. B. Dambaev, S. P. Buryukhaev,

G. Altantsetseg, G. Orkhontuya, R. Yundonperenley

Pavel A. Tkachyov

Master's Student,

Dorzhi Banzarov Buryat State University

24a Smolina St., Ulan-Ude 670000, Russia

pashenka.tkachev.2016@list.ru

Aryuna A. Radnagurueva

Cand. Sci. (Biol.),

Institute for General and Experimental Biology SB RAS,

6 Sakhyanovoy St., Ulan-Ude 670047, Russia

aryuna_rg@mail.ru

Elena V. Lavrentyeva

Cand. Sci. (Biol.),

Institute for General and Experimental Biology SB RAS,

6 Sakhyanovoy St., Ulan-Ude 670047, Russia

lena_1@mail.ru

Tuyana G. Banzaraktsaeva

Cand. Sci. (Biol.),

Institute for General and Experimental Biology SB RAS, 
6 Sakhyanovoy St., Ulan-Ude 670047, Russia

tuyana_banz@mail.ru

Darima D. Barkhutova

Cand. Sci. (Biol.),

Institute for General and Experimental Biology SB RAS,

6 Sakhyanovoy St., Ulan-Ude 670047, Russia

darima_bar@mail.ru

Vyacheslav B. Dambaev

Cand. Sci. (Biol.),

Institute for General and Experimental Biology SB RAS,

6 Sakhyanovoy St., Ulan-Ude 670047, Russia

slavadmb@mail.ru

Saveliy P. Buryukhaev

Cand. Sci. (Biol.),

Institute for General and Experimental Biology SB RAS,

6 Sakhyanovoy St., Ulan-Ude 670047, Russia

bursav@mail.ru

Gandbol Altantsetseg

Research Assistant,

Medical University "New Medicine",

5/2 Tovchoony St., Sonsgolon, Ulaanbaatar 18130, Mongolia

altantsetseg@ncm.edu.mn

Gantulga Orkhontuya

Research Assistant,

Medical University "New Medicine",

5/2 Tovchoony St., Sonsgolon, Ulaanbaatar 18130, Mongolia

orkhontuya@ncm.edu.mn

Radnased Yundonperenley

Research Assistant,

Medical University "New Medicine",

5/2 Tovchoony St., Sonsgolon, Ulaanbaatar 18130, Mongolia

altantsetseg@ncm.edu.mn

Abstract. The article is devoted to the study of actinobacteria in the thermal spring of Mongolia - Ero. In the Ero hot spring, a taxonomic analysis of the microbial community of water, microbial mat and bottom sediments was carried out using the method of high-throughput sequencing for the $16 \mathrm{~S}$ rRNA gene. It was shown that the largest share of actinobacteria was found in hot spring water (up to $42 \%$ ), the smallest variety of actinobacteria was found in samples of microbial mats (up to $0.3 \%$ ). A culture of actinobacteria Nocardia farcinica was isolated from bottom sediments of Ero-19-3 station. The isolated actinobacteria strain is a moderate thermophile with an optimum growth of $45^{\circ} \mathrm{C}$.

Keywords: high-throughput $16 \mathrm{~S}$ rRNA gene sequencing, hot springs, actinobacteria, thermophiles. 
Acknowledgments. The work was performed within the framework of the state assignment No. 121030100229-1.

\section{For citation}

Tkachyov P. A., Radnagurueva A. A., Lavrentyeva E. V., Banzaraktsaeva T. G., Barkhutova D. D., Dambaev V. B., Buryukhaev S. P., Altantsetseg G., Orkhontuya G., Yundonperenley R. Actinobacteria of Thermal Spring Ero (Mongolia). Nature of Inner Asia. 2021; 4(19): 82-91 (In Russ.). DOI: 10.18101/2542-0623-2021-4-82-91

The article was submitted 04.10.2021; approved after reviewing 17.11.2021; accepted for publication 20.12.2021. 